\title{
Metakarp kırıkları
}

\author{
Metacarpal fractures
}

\author{
Mehmet Armangil, Murat Kayıpmaz, Sırrı Sinan Bilgin
}

Ankara Üniversitesi Tıp Fakültesi El Cerrahisi Bilim Dalı, Ankara

\begin{abstract}
Metakarp kırıkları üst ekstremitenin en sık görülen yaralanmalarındandır. Doğru tedavi için iyi fizik muayene ve yeterli görüntüleme önemlidir. Kırığın hangi metakarpta ve hangi seviyede olduğuna, yani kırıkta açılanma, kısalık ve rotasyon derecesine göre konservatif veya cerrahi tedavi belirlenir. Cerrahi tedavide çok sayıda yöntem vardır ve bu sıklıkla kırığın geometrisine bağlıdır. Parmaklarda hareket kısıtlılığını önlemek için uzun süreli tespitlerden kaçınılmalıdır. Basamaklanması 2 mm'den fazla olan eklem içi kırıklar düzeltilmelidir. Segmenter kemik kaybının olduğu kırıklara ciddi yumuşak doku defektleri eşlik eder ve tedavinin ilk basamağında kemik uzunluğunun sağlanması önemlidir. Ulnar karpometakarpal eklem kırıklıçıkıklarının tanısı güç olabilir. Tanıda oblik grafiler ve bilgisayarlı tomografi yardımcıdır.
\end{abstract}

Başparmağın cisim kırıkları, diğer metakarp kırıklarına benzer şekilde tedavi edilir. Bununla beraber, başparmağın kaidesindeki eklem içi kırıklar kayma eğilimdedir ve posttravmatik artrite neden olmaması için daha dikkatli tedavi edilmesi gerekir. Metakarp kırığını tedavi eden hekim, tedavi seçeneklerini bilip, olası risk ve yararları göz önünde tutarsa, metakarp kırığının komplikasyonları oldukça düşüktür.

Anahtar sözcükler: metakarpus; kemik kırıkları; komplikasyonlar
Metacarpal fractures are one of the most common injuries of the upper extremity. Physical examination and the correct imaging are the keys for proper management. Treatment includes conservative or surgical methods due to the fractured metacarpal, the grade e.i., shortening, angulation and rotation of the fracture. In surgical treatment there are lots of options and major issue is the geometry of the fracture. Excessive immobilization should be avoided to prevent stiffness in fingers. More than $2 \mathrm{~mm}$ of intra-articular displacement should be corrected. In case of segmental bone loss, generally severe soft tissue defects are encountered and the height of the metacarpal should be maintained as initial management. The diagnoses of ulnar carpometacarpal fracture dislocations are challenging. Oblique radiographs and computerized tomography are useful in diagnosis.

Thumb metacarpal shaft fractures are treated similarly as the other metacarpals. On the other hand, intra-articular basis fractures including thumb metacarpal are likely to displace and more attention should be paid to prevent posttraumatic arthritis. If the physician treating metacarpal fracture knows the options in treatment and the risks and benefits of them, low rate of complications could be achieved.

Key words: metacarpus; bone fractures; complications
K avrama için ele, el bileği ve parmaklar arasında önemli bir boşluk sağlayan metakarplar, el fonksiyonu açısından oldukça önemlidirler. Fonksiyonel bozuklukları kuvvet ve hareket azalmasına neden olurken kalıcı sakatlık oluşturabilir. Metakarp ve falanks kırıkları tüm kırıkların yaklaşık \%10'nu teşkil eder; metakarp kırıkları ise tüm el kırıklarının \%30-40'nı oluşturur. En sık görülen 5. metakarp boyun kırığıdır (\%10). ${ }^{[1]}$ Metakarp kırıkları direkt veya indirekt mekanizmalarla ortaya çıkmaktadır. Oluşan kırığın veya çıkığın tipi travma esnasında uygulanan kuvvetin özelliğine ve yönüne göre değişebilmektedir. ${ }^{[2,3]}$ Karpometakarpal (KMK) yaralanmalar, yani metakarp kaide kırık ve çıkıkları genelde aksiyel yüklenmeyle ve el bileği ekstansiyonda iken ele gelen yüklenmelerle olmaktadır. Metakarp cisim ve boyun yaralanmaları, tipik olarak aksiyel yüklenme ve direkt travma ile oluşurlar. Parmakları döndüren zorlamalar da bu bölgede kırı̆ga neden olabilir. Metakarp boyun kırıkları ise sıklıkla yumruk atma ile

- İletişim adresi: Yrd. Doç. Dr. Mehmet Armangil, Ankara Üniversitesi Tıp Fakültesi El Cerrahisi Bilim Dalı, Ankara Tel: 0312 - 50823 21, 0532 - 4367107 Faks: 0312 - 3112522 e-posta: mehmetarmangil@yahoo.com

- Geliș tarihi: 25 Subat 2014 Kabul tarihi: 25 Subat 2014 
meydana gelirler. Metakarp baş yaralanmaları eklemiçi kırıklardır ve aksiyel yüklenme veya direkt travma ile oluşurlar. Kopma kırıkları, fleksiyonda olan metakarpofalangeal eklemde meydana gelen zorlanma ile kollateral ligamentlerin yapıştıkları yerin kopma kırığıdır. Metakarpofalengeal (MF) çıkıklardan, dorsal olanlar en sık görülenidir ve parmağın güçlü hiperekstansiyonu ile olmaktadır.

\section{DEĞERLENDIRME}

Travma öyküsünün ayrıntıları, eksiksiz fizik muayene, kırı̆̆ı ve özelliklerini gösterecek doğru radyolojik incelemeler, doğru klinik değerlendirme için gereklidir. Açık yara olması ve dizilim bozukluğu tedavide belirleyicidir. Açılanma derecesi bulunduğu yere ve etkilenen metakarpa göre farklı klinik önem taşır. Kısalık, ekstansör fonksiyonu etkiler. Rotasyon ise parmaklarda makaslamaya bağlı fonksiyon bozukluğuna neden olduğundan kabul edilemez ve düzeltilmesi gerekir. Bu nedenlerden dolayı, parmaklar fleksiyon ve ekstansiyonda muayene edilmelidir. Tırnakların dizilimi ekstansiyonda bir paralellik göstermelidir. Parmaklar fleksiyona getirildiğinde birbirlerinin üzerine binmeksizin, dizilimleri skafoid tüberositeyi göstermelidir. Hastanın normal tarafının muayenesi, o kişide olan farklııkla$\mathrm{rı}$ anlamada önemli ve gereklidir. Değerlendirmede standart olarak posterior-anterior (PA), lateral ve oblik grafiler kullanılır. Skyline ve Brewerton grafisi gibi, metakarp başlarının daha iyi görülmesini sağlayan ve Robert grafisi gibi başparmak kaidesini gösteren özel pozisyonlar kullanılabilir. ${ }^{[4,5]}$ Uygun pozisyonda ve kaliteli direkt grafi çekilmesindeki problemler ve iyi pozisyonlamanın yapılamaması nedeniyle metakarp kırıklarında doğru tanının zor olduğu akılda tutulmalıdır. Tanı atlamamak için iyi klinik muayene yapılmalı ve uygun pozisyonlardaki grafilerin iyi değerlendirilmesi gereklidir; icabı halinde grafi tekrarlanmalıdır. Direkt grafilerin yeterli olmadığı, özellikle eklem çevresi yaralanmalarda bilgisayarlı tomografi (BT) kullanılmalıdır. [6] Literatürde ameliyat öncesi değerlendirmede özgün kanıt ortaya konamamıştır. ${ }^{[7]}$

\section{ENDIKASYONLAR}

Metakarp kırıklarının çoğu, kapalı düzeltme ve alçı atelle hareketsizlik sağlanarak veya dorsal bloklayıcı atelle sağlanan kontrollü hareket ile cerrahi olmayan yöntemlerle tedavi edilebilmektedir. Cerrahi tedavi endikasyonları;

1. Kapalı tekniklerle düzeltme ve tespitin sağlanmadığı kırıklar,

2. Açık kırıklar,
3. Çoklu el kırıkları,

4. Kompleks yaralanmalar,

5. Yer değiştirmiş eklem-içi kırıklar,

6. Kararlı iskelet gerektiren ciddi yumuşak doku kaybı olan kırıklar olarak özetlenebilir.

\section{Metakarp baş kırıkları}

MF eklemler kavramada kilit rol oynar; eklem yüzeyinde bozulma kabul edilmemelidir. Eklem yüzeyi restorasyonu esastır; direkt grafide görülebilen yer değiştirme düzeltilmelidir; cerrahi tespit gereklidir. ${ }^{[8]}$ Bu kırıklar genellikle direkt travma ile oluşur; açık yaralanma varsa yumruğun dişle temasından şüphelenmek gerekir. Bu tip yaralanmalar, cerrahi debridman, tamir (kemik+tendon) ve parenteral antibiyotik tedavisini gerektirir. ${ }^{\left[{ }^{[9]}\right.}$ Belirgin olmayan yer değiştirme varsa yakın takiple konservatif tedavi denenebilir; kontrollü erken harekete başlanması, oluşacak eklem hareketi kaybını engelleyebilecek tek çözümdür. ${ }^{[9]}$ Yer değiştiren eklem yüzü içeren parçalar anatomik olarak düzeltilmeli ve cerrahi olarak tespit edilmelidir; tespit için K-telleri, başlı ve başsız kompresyon vidaları, biyoemilebilir malzemeler kullanılabilir (Şekil 1). İyi tespit erken harekete izin vermelidir; böylece hareket kısıtlılığı azaltılabilir. Ancak, yine de tüm kırıklarda mükemmel sonuç elde etmek mümkün olmayabilir. ${ }^{[10]}$ Çok parçalı kırık, yer değiştirme ve yumuşak doku yaralanması prognozu kötüleştirir (Şekil 2). [10,11]

Metakarp başında avulsiyon kırıkları özellikle kenar parmaklarda görülmektedir. ${ }^{[9]}$ Tipik örneği, başparmak ulnar kollateral ligament yaralanmasıdır. Bir bağ yaralanması olmasına rağmen, küçük kopma kırığı eşlik edebilir. Kırık parça 2 mm'den fazla deplase ve MF eklem karasız ise cerrahi tedavi gereklidir. Kırık parça küçük ise veya işlem sırasında parçalanırsa eksize edilip birincil bağ tamiri yapılabilir. Büyük parçalar K-teli veya vida ile tespit edilebilir. Tamirin korunması için 4-6 hafta süreyle başparmağı içeren alçı uygulaması ve eklemi geçen K-teli uygulanmalıdır (Şekil 3).

İşaret parmağında olan radyal kollateral bağ yaralanması atlanmamalıdır; bu bağ, çimdikleme fonksiyonunun önemli bağıdır. ${ }^{[4]}$ Benzer şekilde, beşinci parmağın benzer lezyonu kalıcı abduksiyon deformitesine neden olacağı için önemlidir. Tam yırtıklarda, stres verildiğinde son nokta genelde yoktur ve hissedilmez. Freeland, tam yırtıkta bile $30^{\circ}$ 'de immobilizasyon sonrası artan hareketle tedaviyi önermektedir. ${ }^{[12]}$ Kopma kırığı küçük bir parça (eklemin \%20'sinden küçük) ve ayrılmamışsa ( $2 \mathrm{~mm}$ 'den az) yandaş parmağa bantlama yapılarak erken hareketle tedavi edilebilir. ${ }^{[4,6]}$ Bunların dışında kalan kopma kırıklarında tedavi, cerrahi tespit sonrası erken harekettir. ${ }^{[6,9]}$ 

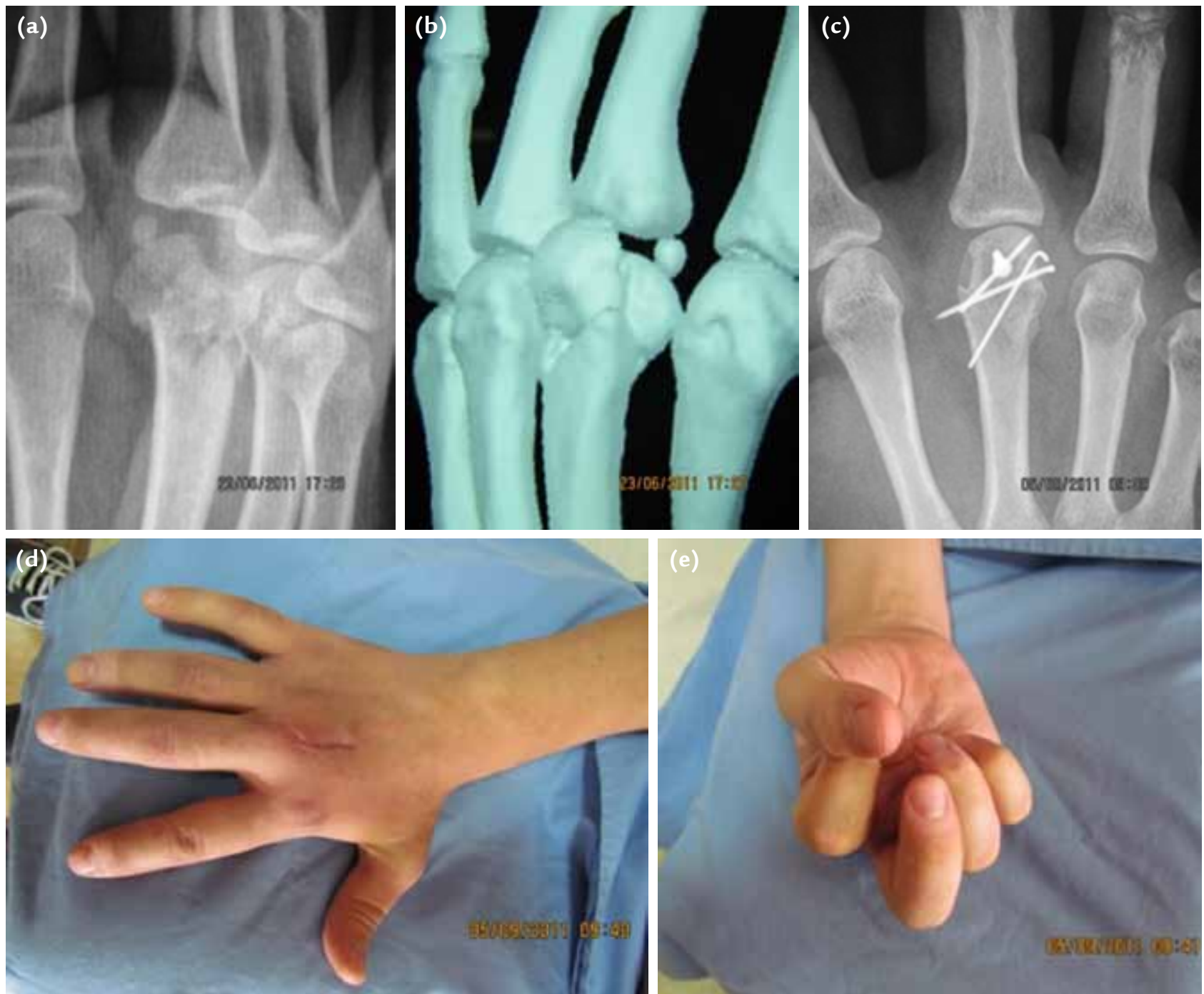

Şekil 1. a-e. Üçüncü metakarp başı eklemiçi kırığı (a). Kırığın üç boyutlu tomografi görüntüleri (b). Açık redüksiyon, K-teli ve vidalar ile tespit (c). Ameliyattan iki ay sonraki fonksiyonel görüntü (d). Üçüncü metakarpofalangeal eklemde fleksiyon kıstlılığı görülmekte (e).

\section{Metakarp boyun kırıkları}

En sık 4. ve 5. metakarpta görülür ve genelde sert bir cisme yumruk atma sonucu oluşur. Tedavi, kırığın hangi metakarpta olduğu, kırık sonucu oluşan açılanmanın derecesi, elde yalancı pençeleşme ve rotasyonun varlığına göre yapilır; klinik muayenede rotasyon kontrol edilmiş olmalıdır (Şekil 4). Dördüncü ve 5. KMK eklemler daha hareketli olduğu için 4. ve 5. parmaklar açılanmayı daha iyi tolere eder. Bazı yazarlar $70^{\circ}$ 'ye kadar açılanmayı kabul etse de, $30^{\circ}$ üzerindeki açılanmalar parmak hareketini bozabilir ve fleksör dijiti miniminin kuvvetini azaltır. ${ }^{[13,14]}$ Bu yüzden $40^{\circ}$ üzerinde olan açılanmalarda düzeltme yapılmalıdır. Ancak aynı bilgiler 2. ve 3. metakarplar için geçerli değildir; 2. ve 3. metakarplarda $15^{\circ}$ ye kadar açılanma kabul edilir. ${ }^{[6,8,15]}$
Çoğu metakarp boyun kırığı konservatif yöntemle tedavi edilir. Eğer metakarpta açılanma yukarıda belirtilen değerlerin üzerinde ise, Jahss manevrası ile açılanma ve varsa rotasyon düzeltilir (Şekil 5). El bilek $30^{\circ}$ ekstansiyonda, MF eklem $70-90^{\circ}$ fleksiyonda, parmaklar nötralde, ulnar oluklu atel ile hareketsizlik sağlanır (Şekil 6). ${ }^{[9]}$ İki ila üç haftanın sonunda atel çıkarılır ve parmak egzsersizlerine başlanır. Günlük uygulamada en çok rastlanan sorun ekstansiyonda redüksiyon ve MF eklem tam ekstansiyonda atellemedir. Bu tip tespit MF eklemlerde kollateral ligament kontraktürüne ve MF eklem sertliğine yol açar. Aslında metakarp boyun kırıkları Jahss manevrası ile çok kolay redükte olmaktadır, MF eklem fleksiyona alındıkça elde edilen düzeltmeyi korumak da kolaylaşmaktadır. 


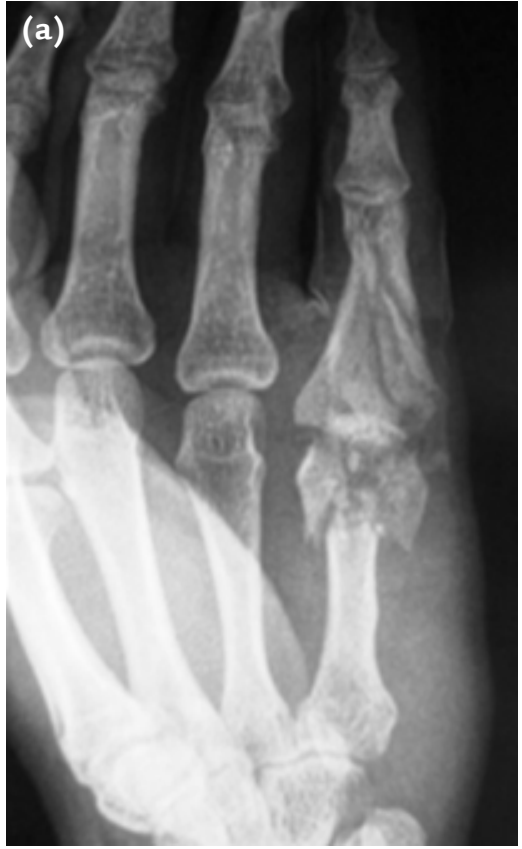

(d)

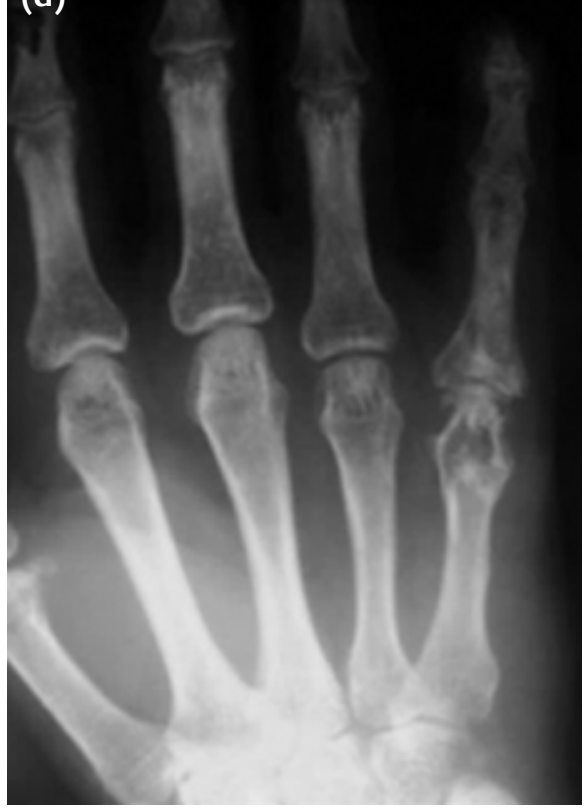

\section{(b)}

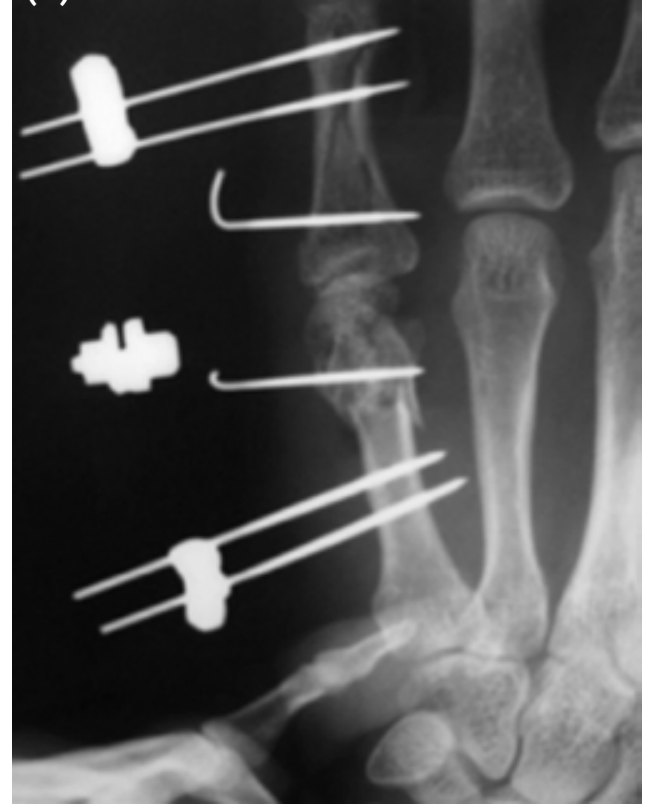

Şekil 2. a-d. Beşinci metakarp baş ve proksimal falanks kaidesinin kombine parçalı eklem içi kırığı (a). Kırıklar, perkütan K-telleri ve eksternal fikastör ile tespit edildi (b). Aynı hastanın erken ameliyat sonrası görüntüsü (c). Eksternal fiksatör ve K-telleri çıkarılmış ve parmak dizilimi görülmekte (d).
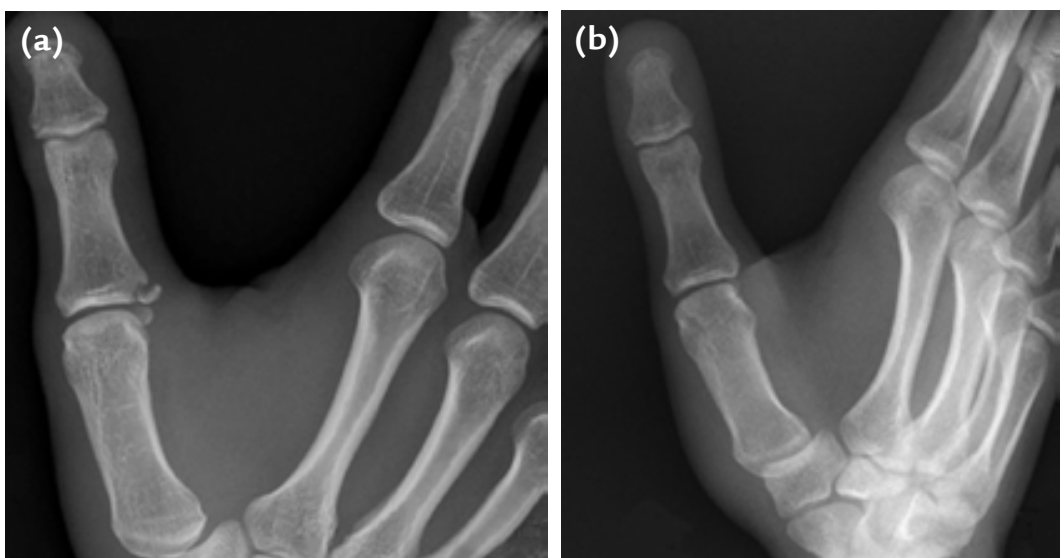

Şekil 3. a, b. Başparmak proksimal falanks ulnar kollateral kopma kırı̆̆ı (a). Açık redüksiyon K-teli ile tespit sonrası, ikinci yılda çekilmiş grafi görüntüsü (b).
Ancak, Hofmeister, atel uygulamasında MF eklemin ekstansiyonda veya fleksiyonda olmasının fonksiyonel sonuçlarda bir fark yaratmadığının kanıtını (Seviye I) ortaya koymuştur. ${ }^{[16]}$ Poolman ise, Cochrane derlemelerini gözden geçirmiş ve herhangi bir atelleme protokolunun üstünlügünü (Seviye II) gösterememiştir. ${ }^{[17]}$ Tedavi yöntemine bağlı olmaksızın, olgularda üçüncü ay sonundaki fonksiyonel sonuçlar aslında benzerdir. ${ }^{[9]}$

Eğer kapalı yöntemle kırık redükte edilemiyor veya redüksiyon devamı sağlanamıyorsa, çok parçalı kırık gibi kırığı kararsız hale getiren durum mevcut ise, cerrahi tedavi düşünülür. Cerrahi tedavide en sık kullanılan yöntem, kapalı düzeltme sonrası K-teli ile veya kanal-içi tellerle yapılan tespittir. Bununla beraber, eğer dizilim ve düzeltme elde edilemezse açık redüksiyon, plak ve vida ile tespit uygulanabilir. Çok parçalı kırık ve tendon yaralanması birlikteliğinde, içerden tespit uygulanacak ise erken harekete izin veren mini kondiler plak diğerlerine tercih edilebilir; ancak cerrahi teknik önemlidir. ${ }^{[6,9]}$ Konservatif veya cerrahi tedavi yaparken 


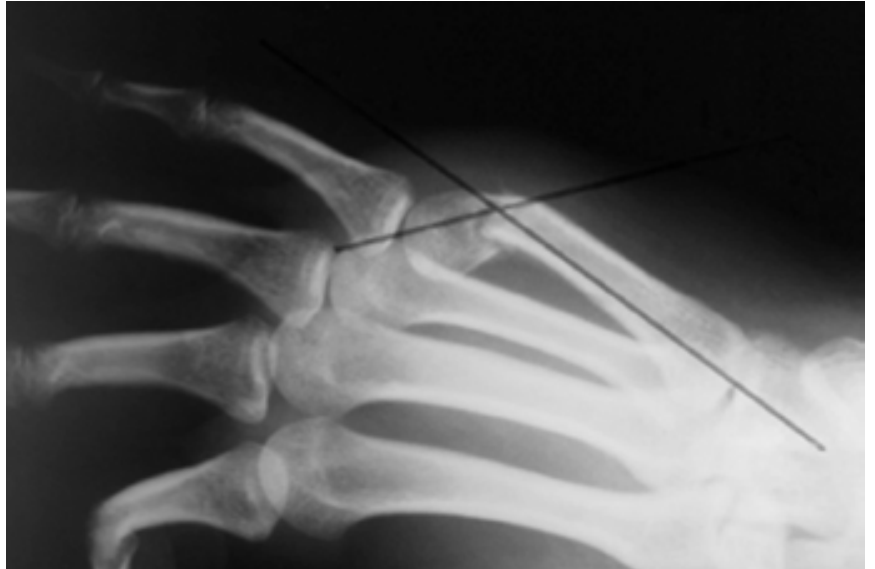

Şekil 4. Beşinci parmak boyun kırığı. Kırıktaki açılanmanın derecesi, distal ve proksimal parçaların orta hatların geçen çizgilerin kesişmesiyle oluşan açı ile belirlenir. Ölçülen açının elin pozisyonuna göre değişebileceği akılda tutulmalıdır.
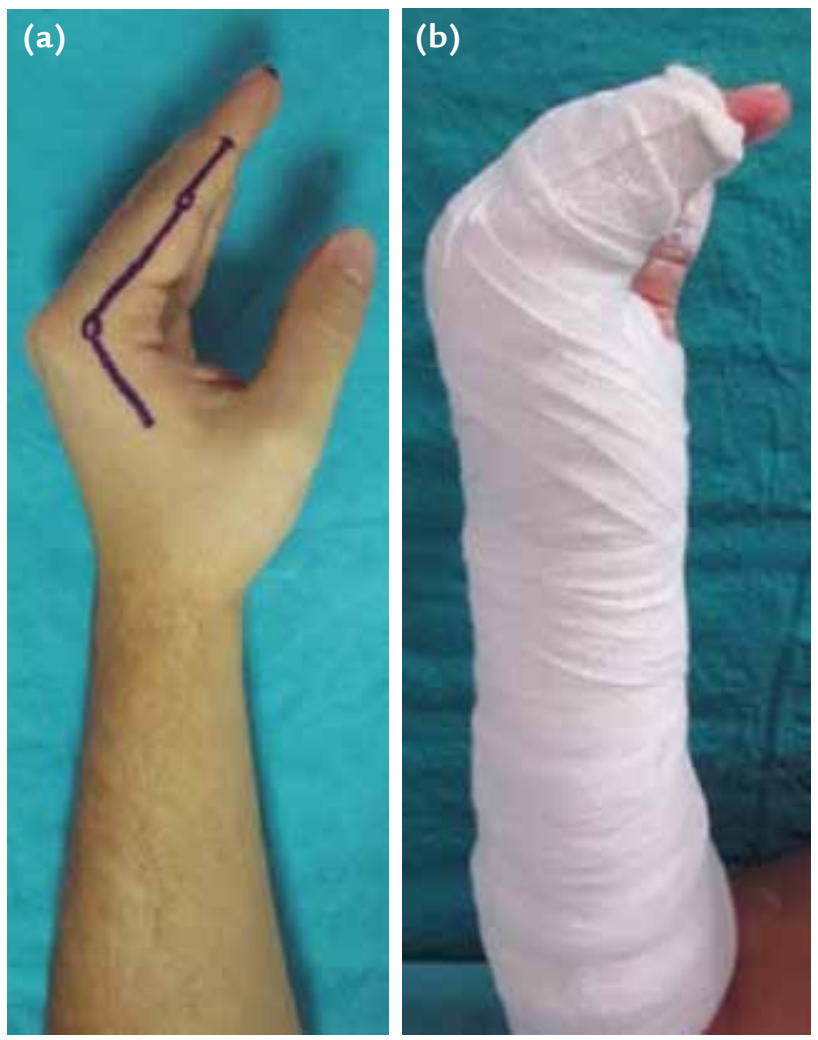

Şekil 6. a, b. Metakarp kırıklarının tedavisinde eklem kontraktürünü engellemek için el bilek $30^{\circ}$ ekstansiyonda, MF eklem $70-90^{\circ}$ fleksiyonda, parmaklar nötralde atelleme (a). Ulnar oluklu atel (b).

unutulmaması gereken en önemli noktalar; MF eklemin üç haftadan fazla hareketsiz bırakılmaması ve aksi takdirde ekstansiyonda immobilize edilen MF eklemde hareket kısıtlılığı gelişebileceği olarak özetlenebilir.

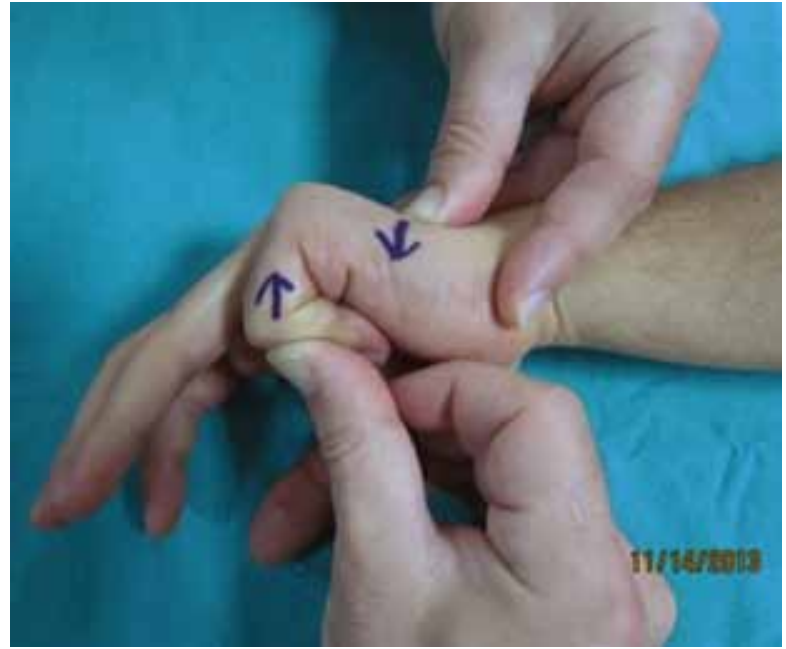

Şekil 5. Beşinci metakarp boyun kırığını redükte etmek için kullanılan Jhass manevrası.

\section{Metakarp cisim kırıkları}

Metakarp cisim kırıkları genel olarak transvers, oblik veya spiral ve parçalı kırık olarak 3 tipte sınıflandırılır. Transvers kırıklar genellikle aksiyel yüklenmeler sonucu meydana gelir ve apeksi dorsale açılanmış deformiteye neden olur. ${ }^{[12,15]}$ Kabul edilen açılanma miktarı tutulan metakarpa bağlıdır, daha distal ve daha ulnar metakarp kırklarında daha fazla açılanma kabul edilebilir. Spiral ve oblik kırıklar döndürücü yüklenmeler sonucu oluşur ve rotasyonel dizilim bozukluğuna neden olur. Malrotasyon, en iyi parmaklar fleksiyona getirilerek yapılan fizik muayenede saptanır. Genelde iyi tolere edilemez ve düz grafilerde saptamak zordur. Metakarp cisminde olan $10^{\circ}$ rotasyon bozukluğu, parmaklar fleksiyona geldiğinde $2 \mathrm{~cm}$ 'lik üst üste binmeye neden olmaktadır. ${ }^{[18]}$ Malrotasyon varlığında açık redüksiyon düşünülmelidir. Genelde konservatif tedavi kriterleri farklı olabilmekle beraber:

1. Rotasyonel deformite kabul edilmemelidir.

2. İkinci ve üçüncü metakarpta $5-10^{\circ}$ 'nin altında açılanma ve 2 mm'den az kısalma kabul edilebilir.

3. Dördüncü ve beşinci metakarpta $15-20^{\circ}$ 'nin altında açılanma ve 3-4 mm'den az kısalma genellikle kabul edilebilir. ${ }^{[6]}$

Konservatif tedavide, kapalı düzeltme sonrası genellikle dorsal açlanma olduğu için dorsalden kuvvet uygulanması gerekli olmaktadır; alçı atel tespiti gereklidir. El bileğinin nötralde veya hafif ekstansiyonda olması, MF eklemlerin $70-90^{\circ}$ fleksiyona alınması (intrensek-plus pozisyonu), MF kontraktürleri engellemesi ve deforme edici intrensek kasları gevşetmesi nedeniyle avantajlıdır. ${ }^{[6]}$ Hareketsiz bırakma süresi 3-4 haftayı geçmemelidir. 
Çoklu metakarp kırıkları, kenar parmaklardaki yer değiştirmiş kırıklar, çok parçalı veya açık kırıklar genelde cerrahi tedavi gerektirir. ${ }^{[9]}$ Takipte, yukarıdaki sınırların dışına çıkan kırıklar da cerrahiye aday kabul edilirler. Uzun oblik cisim kırıkları kararsız oldukları için cerrahi tedavi önerilmektedir. Ancak Al-Qattan, bu tip kırıkları palmar splint ve erken mobilizasyon ile tedavi etmiş ve mükemmel fonsiyonel sonuçlar bildirmiştir. [19]

Tedaviyi yönlendirecek cerrah tüm yöntemleri bilmeli ve hasta için en doğru olanı uygulayabilmelidir.

Cerrahi tedavide kapalı düzeltme ve perkütan tespit, transvers kırıklar ve kısa oblik kırıklar için oldukça uygundur. Çapraz K-telleri dönmeye karşı direnci arttırırlar. ${ }^{[20]}$ Temelde metakarp başlarının yan tarafları, kollateral bağın yapıştığı bölge tel girişi için uygundur; telleme distalden proksimale yapılır; gerekiyorsa tel KMK eklemi geçebilir. ${ }^{[6]}$ ikinci ve beşinci metakarplardaki bu tip kırıklarda, 3. veya 4. metakarp sanki eksternal fiksatör gibi kullanılarak, kemiklere düzeltme sonrası dik açıyla konan teller de tespit yöntemi olarak kullanılabilir. ${ }^{[9]}$

Metakarp cisim kırıklarında cerrahi tespit yöntemini, aslında daha çok kırık geometrisi belirler. ${ }^{[6,9]} \mathrm{Biz}$ kliniğimizde, uzun oblik veya spiral kırıklarda (en az kemik çapının iki katı uzunluğunda kırık hattı) mini vidalarla tespiti tercih ediyoruz. Vidaları kırık hatlarına dik (çektirme vidası prensipleri) olarak koyuyor ve "iki vida arasındaki olabilecek en kısa mesafe kullanılan vida başı kadar olmalıdır” prensibini kullanıyoruz (Şekil 7). Kanal içi çiviler veya teller de kemik tespiti için kullanılabilir; rotasyonel kararlılıkları çok iyi olmamakla beraber, kanal içini dolduran birden çok önceden eğilmiş teller avantajlı olabilir. ${ }^{[21,22]}$ Plak-vida tespiti birçok kırık tipinde güvenle kullanılabilir; kilitli plak-vida sistemleri daha az vida ile daha iyi kararlılık sağladığı için avantajlıdır. Plak, ektansör tendonun fonsiyonunu bozmaması amacıyla metakarpın dorso-lateraline yerleştirilmelidir. Transvers, kısa ve uzun oblik, çok parçalı, osteoporotik ve eklem çevresi kırıklarda plak-vida tespiti kullanılabilir. Ameliyat sonrası, kendi tecrübemizde, ekstansör tendon irritasyonu, yapışıklık ve sinovit gibi problemlerle karşılaştığımız için, plak-vida tespiti birincil tercihimiz olmamakla beraber güvendiğimiz bir yöntemdir. Sıklıkla tercih ettiğimiz plak-vida sistemleri 2,0-2,7 mm'lik kilitli kompresyon plaklarıdır. Metakarp kırığı tespitinde plak-vida kullanılmış ise, ameliyat sonrası immobilizasyon uygulamamak gereklidir (Şekil 8).
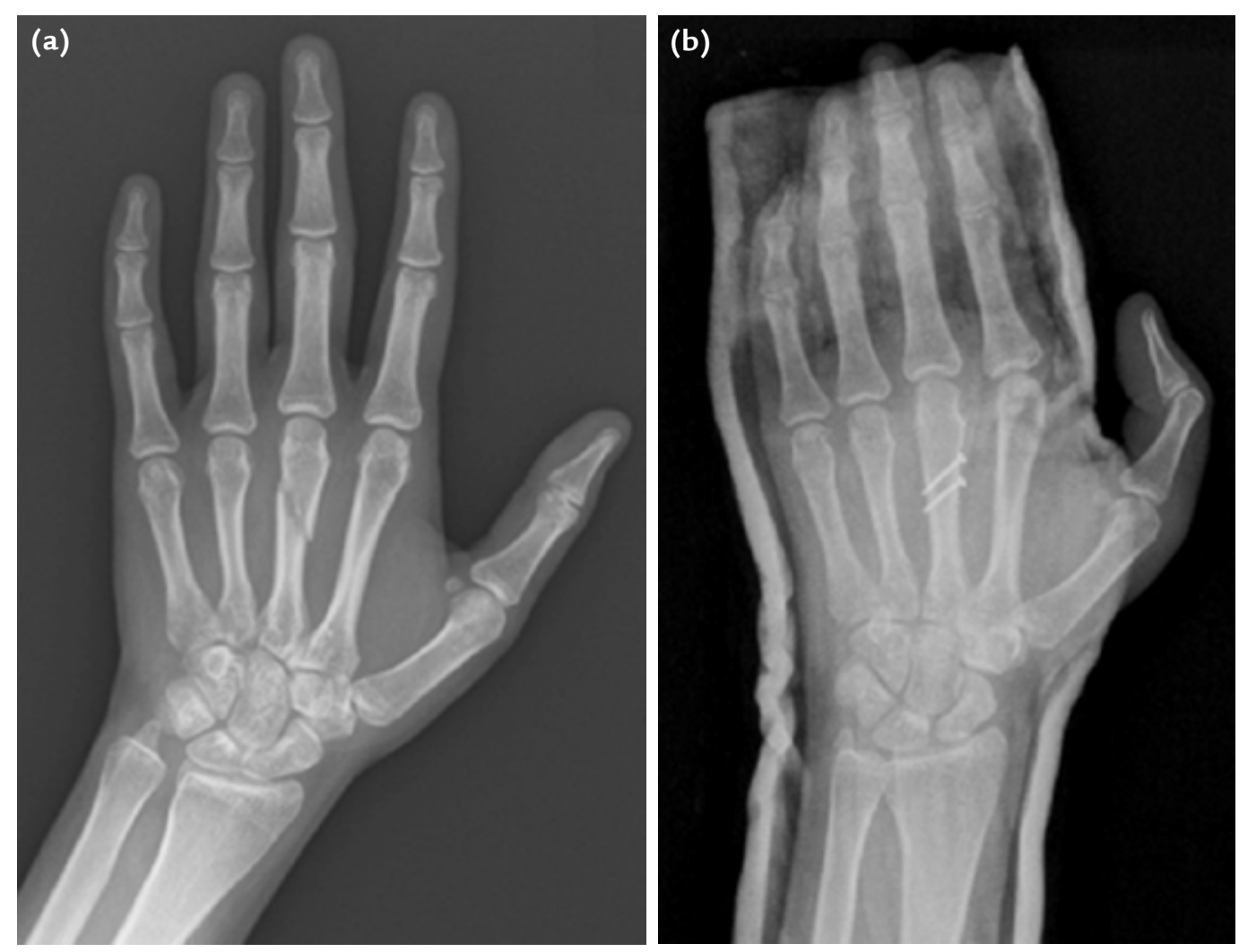

Şekil 7. a, b. Üçüncü metakarp oblik cisim kırı̆̆ı (a). Kırık mini interfragmanter vida ile tespit edildi (b). 


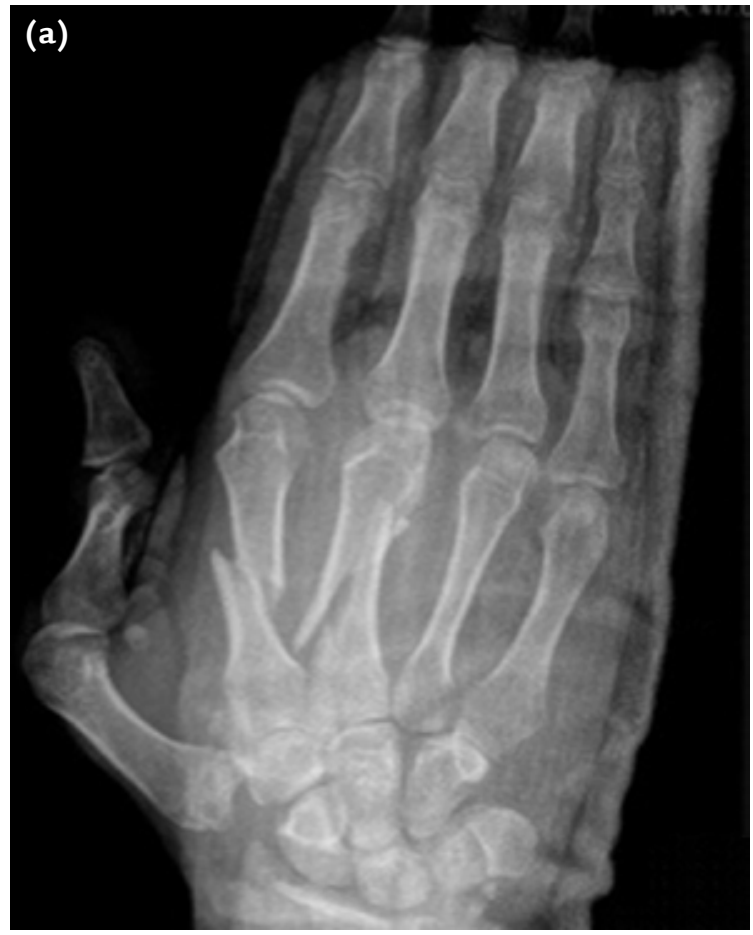

\section{(b)}
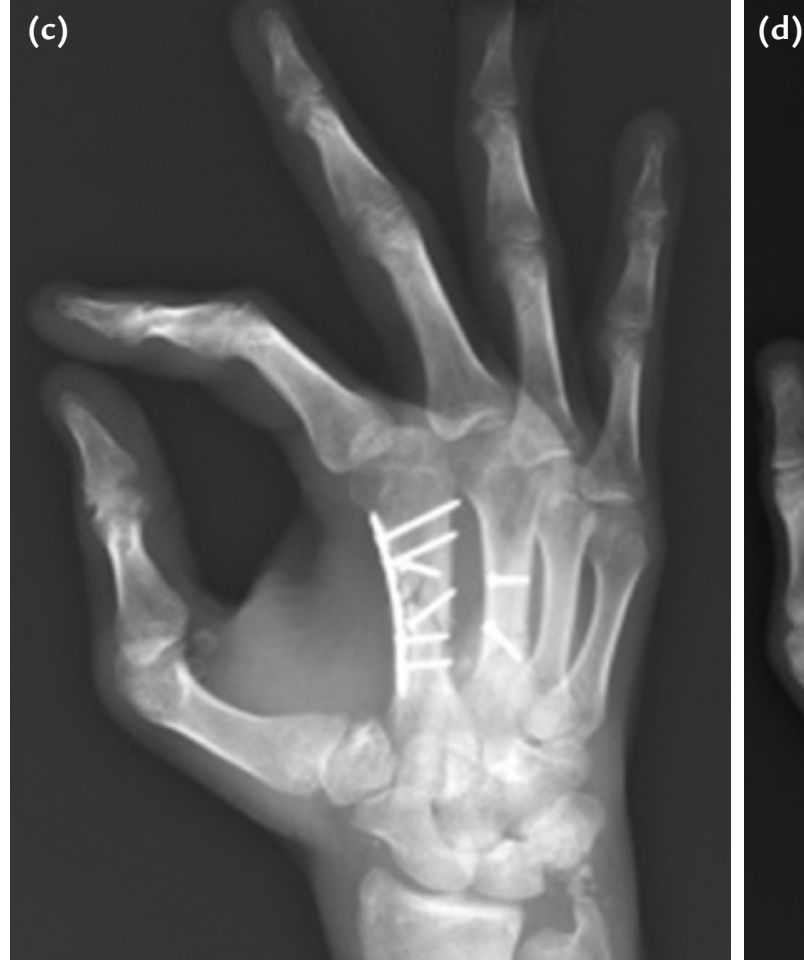

Şekil 8. a-d. İkinci ve üçüncü metakarp parçalı kırıklarının ön arka ve oblik grafileri (a, b). İkinci metakarp plak-vida ile, 3. metakarp vida ile tespit edildi $(c, d)$.

Dışardan tespit sistemlerini (eksternal fiksatör) kliniğimizde ilk tercih olarak kullanmıyoruz. Kemik kayıplı açık kırıklarda bile geçici tespiti, kısalmaya neden olmayacak şekilde teleskopik konan K-teli ile yapmayı tercih ediyoruz. Dışarıdan tespit, açık kırıklarda, enfeksiyonda, çok parçalı kırıklarda ve kemik eksikliği olan durumda kullanılabilecek bir yöntemdir. ${ }^{[8]}$ 


\section{Metakarpal kaide kırıkları ve karpometakarpal kırıklı-çıkıklar}

Bu bölge kırıkları göreceli olarak stabildir, çünkü eklemler dorsal ve palmar bağlar ve interosseöz bağlar tarafından sıkıca desteklenmiştir. Dördüncü ve beşinci KMK eklemler, 2. ve 3. KMK eklemden daha hareketli olduğu için, 4. ve 5. metakarp kaide kırıkları daha kararsızlık gösteren kırıklardır. Ekstansör karpi radyalis longus, ekstansör karpi radyalis brevis ve ekstansör karpi ulnaris, sırasıyla 2., 3. ve 5. metakarp tabanında avulsiyon kırıklarına neden olabilir ve bunların direkt grafi ile tanısı zordur. Bu bölge kırıkları genelde yüksek enerjili yüklenmeler sonucu oluşur. Eklem bölgesinde şişlik, hassasiyet, ekimoz, abrazyon ve palpe edilebilir parça varlığında, karpometakarpal patolojilerden şüphelenilmelidir. Özellikle 4. ve 5. metakarp kaide kırılarında, elin ulnar sinir motor fonksiyonları değerlendirilmelidir. Kaide kırıklarında, başka bir kırık daha olma ihtimali vardır; karpal kırıklar ve metakarp boyun kırığı açısından hasta değerlendirmesine dikkat edilmelidir. [23,24] Kırığın tanısı PA, lateral ve oblik grafilerle doğrulanmalıdır. BT, kırığı ve gerçek patolojiyi ortaya koymakta çok yararlı ve gereklidir. ${ }^{[6,8]}$

Metakarp kaide kırıklarını, yaklaşımın daha anlaşılabilir olması bakımından eklem-içi ve eklem-dışı olarak ayırmak kolaylık sağlar. Eklem-dışı kırıkların tedavi yaklaşımı, temelde cisim kırıkları ile aynıdır. ${ }^{[8]}$ Cerrahi tedavide kapalı redüksiyon ve K-teli ile tespit, uygulama kolaylığı açısından tercih edilmektedir; K-teli tespitinde, telin KMK eklemi geçmesi tespitin kararlığını arttırır (Şekil 9). ${ }^{6,8]}$ Açık redüksiyon ve plak-vida tespitinde proksimalde tutunmayı arttırmak için, T-plak gibi plaklar avantajlıdır. Proksimale konan vidaların, özellikle hareketli olan 4. ve 5. KMK ekleme girmediğinin radyolojik olarak kontrolü önemlidir. ${ }^{[8]}$

Eklem-içi kırıklar anatomik düzeltmeyi gerektirir; bu bölgede olan yaralanmalarda en sık yapılan hata, kırıkla beraber olan çıkığın atlanmasıdır. ${ }^{[8]}$ İyi bir fizik muayene ve patolojiyi daha iyi ortaya koyabilmek için BT önemli ve gereklidir. ${ }^{[8,9]}$ Kırık parçalarında yer değiştirme yoksa konservatif tedavi tercih edilen yöntemdir. Cerrahi tedavi de eklem yüzü düzeltmesi gerektiği için, daha çok açık düzeltme ve içerden tespit kullanılmaktadır. Kapalı düzeltme ve perkütan tespit kullanılabilir, ancak eklem içi düzeltmenin tam olup olmadığını skopi kontrolünde anlayabilmek çok da kolay değildir. ${ }^{\left[{ }^{[8]}\right.}$ Açık düzeltme yapıldığında, tespit için K-telleri ve/veya vida tespiti kullanılabilir. ${ }^{[6,8,9]}$

KMK eklem çıkıklarında klinik yaklaşımı;

1. Merkez KMK çıkıkları (2. ve 3. KMK eklemler),

2. Ulnar KMK çıkıklar (4. ve 5. KMK eklemler) olarak ayırmak kolaylık sağlar. ${ }^{[8]}$
Merkez KMK eklem kırıklı-çıkıkları genelde dorsale doğru olur; sıklıkla komşu metakarpların cisim kırığı eşlik eder, atlanmamalıdır. ${ }^{[8]}$ Akut kırıklı-çıkıklarda yerine koyma aslında kolaydır; ancak, bu yaralanmalar kararsız olduğu için yerine konulan eklem genelde yerinde durmaz. ${ }^{[6,8]} \mathrm{Bu}$ yüzden, perkütan K-teli ile tespit gereklidir. Yerine konamayan veya geç gelen olgularda, tercih edilecek tedavi yöntemi açık yerine koyma ve içerden tespittir. ${ }^{[6,8]}$ Yerine koymadan sonra, eklemden geçen tespit veya metakarp kaidelerinin birbirine tespiti ile, kararlılık cerrahi olarak sağlanmalıdır. Tek başına çıkık olması, buna kırı̆ğ eşlik etmemesi nadir bir durumdur; tedavi prensipleri kırıklı-çıkıklar ile aynıdır. Bu iki eklemde hareket çok az olduğu için, eklem sertliği problem yaratmaz ve eklemi geçen tespit teknikleri kullanılabilir. ${ }^{[8]}$

Ulnar KMK eklem kırıklı-çıkıkları, kırık olmadan, sadece çıkık görülen olgulara göre daha fazladır. En sık etkilenen, en geniş hareket arkına sahip olan 5 . KMK eklemdir. ${ }^{[8]}$ Ters Bennett kırı̆ğ, başparmakta olan kırığa benzer ve eklem-içi olan kırık parça yerinde kalırken metakarp kaidesi dorsale ve proksimale çıkar veya sukblukse olur; hamatumda da kırık görülebilir. ${ }^{[8]}$ PA grafide, eğer dikkat edilmezse, kırıklıçıkığı atlamak kolaydır; muayene ve grafinin dikkatli değerlendirilmesi esastır; metakarpta kısalma önemli bulgudur. ${ }^{[8]}$ Yan veya oblik grafide kemiksel yapılar üst üste geldiği için değerlendirmede aksaklık olabilir; $30^{\circ}$ pronasyonda yan grafi, eklem içi yaralanmayı ve patolojiyi iyi gösterir. Tanı sorunu hala devam ediyorsa, BT önemli yardımcıdır. ${ }^{[8]}$ Akut olgularda kapalı yerine koyma, eğer el dorsalinde çok fazla şişlik yoksa nispeten kolaydır; ancak, bu yaralanmalar kararsız olduğu için, kırıklı-çıkık yerine konduktan sonra perkütan K-teli ile tespit gerekir (Şekil 9). ${ }^{[6,8]}$ Yerine konamayan olgularda, açık yerine koyma, eğer hamatumda da büyük parçalı kırık varsa hamatum kırığını vida ile tespit ve yerine koyulan KMK eklemi kararlı halde tutmak için K-teli veya parçaya özel vida tespiti gerekli olabilir. ${ }^{[8]}$ Geç gelen olgularda, açık yerine koyma, "bu eklemlerin hareketli olması gerekir" prensibinden dolayı önerilmez. Hareket verilmesi ve semptomatik olan olgularda geç uygulanan artrodez, izlenmesi gereken yoldur. ${ }^{[6,8]}$

KMK eklemlerin kompleks yaralanmaları vardır; bunlar aksiyel yüklenmeyle beraber makaslama kuvvetlerinin etkili olduğu yüksek enerjili yaralanmalardır. ${ }^{[9]}$ Garcia-Elias bu yaralanmaları;

1. Aksiyel-ulnar ayrılma,

2. Aksiyel-radyal ayrılma (en sık görülen) ve

3. Aksiyel-radyal-ulnar ayrılma olarak üçe ayırmıştır. ${ }^{[25]}$ 

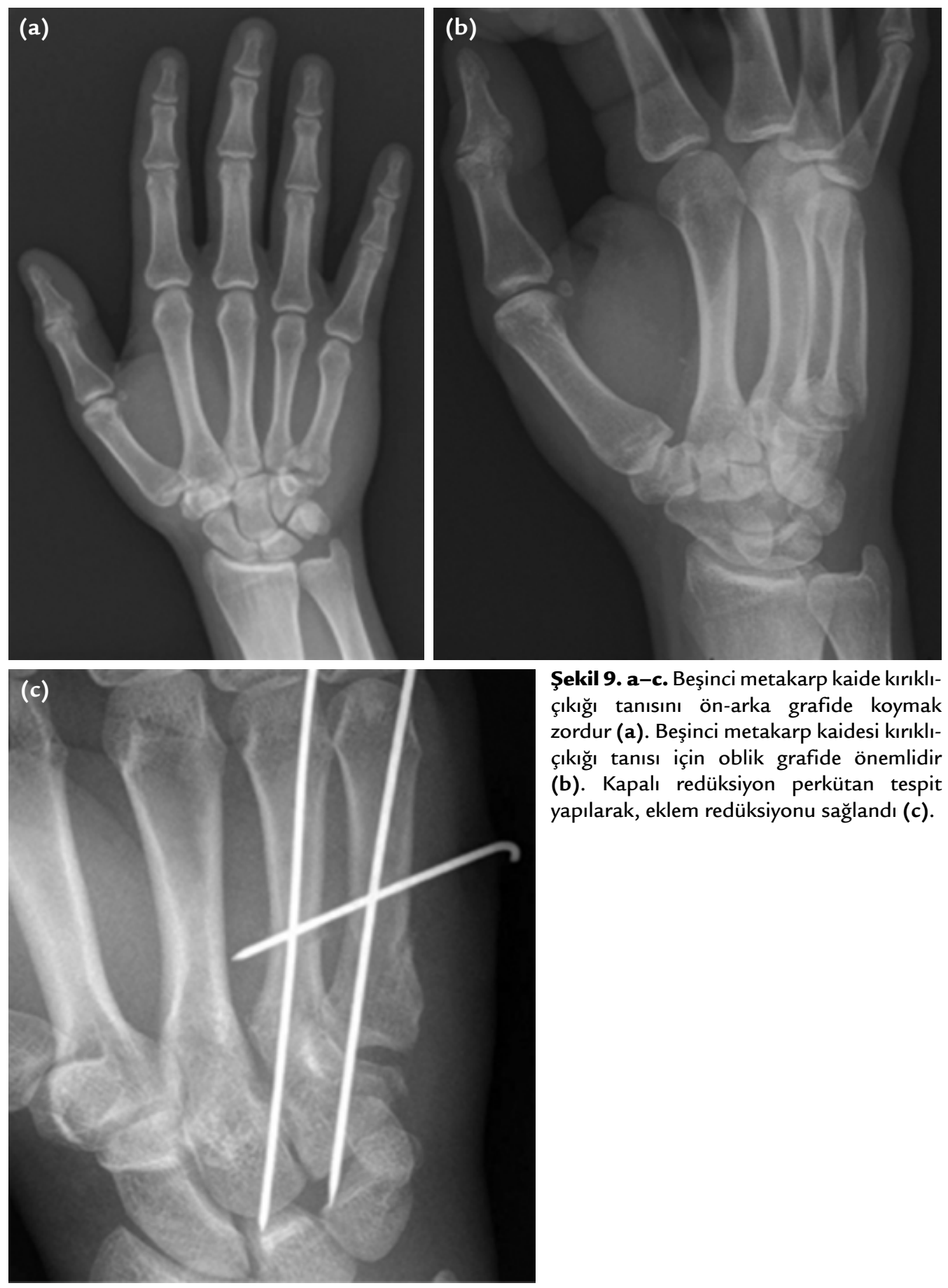

Şekil 9. a-c. Beşinci metakarp kaide kırıklıçıkığı tanısını ön-arka grafide koymak zordur (a). Beşinci metakarp kaidesi kırıklıçıkığı tanısı için oblik grafide önemlidir (b). Kapalı redüksiyon perkütan tespit yapılarak, eklem redüksiyonu sağlandı (c).

Bu tip yaralanmalar genelde atlanır. El dorsalinin çok şişmesi belirgin deformiteyi gizleyebilir; el ayası genişlemiş ve metakarpların oluşturduğu kemer bozulmuştur; eşlik eden geniş yumuşak doku yaralanması görülebilir. ${ }^{[9]}$ Tanıda özel pozisyonlu grafiler yardımcı olur; ancak, son yıllarda geliştirilen üç boyut rekonstrüksiyonlu
BT, patolojinin tanınmasında çok değerlidir. ${ }^{[25]}$ Bu tip yaralanmalarda kapalı yerine koyma, aşırı şişlik ve eşlik eden yaralanmalar nedeniyle pek mümkün değildir; kullanılacak yöntem, açık redüksiyon ve K-teli ile tespittir. 


\section{Başparmak metakarp cisim ve baş kırıkları}

Başparmak metakarp baş ve cisim kırıkları, diğer metakarp kırıklarına benzer tedavi edilir. Başparmak KMK ekleminin hareket genişliğinden dolayı, başparmağın kalıcı deformitesi diğer parmaklardan daha az kısıtlayıcıdır. Frontal planda $15-20^{\circ}$, sagittal planda $20-30^{\circ}$ açılanma fonksiyonel kısıtlılık yaratmaz. ${ }^{6,15]}$ Açılanmanın saptanmasında gerçek PA ve yan grafiler alınmalıdır; kemik uçlarının karşılıklı gelme oranı \%50 ve üzerinde olmalıdır. Başparmak metakarp cisim kırıkları, genelde proksimal metafizyodiyafizer bileşkede olmaktadır. Longitudinal traksiyon ve kırık apeksine bası ile düzeltme sağlanır. Düzeltme sonrası bu bölge kırıkları genelde kararlı halde kalır; iyi oturtulmuş başparmak alçısı ile dizilimin devamı sağlanır. Eğer kırık kararsız ise ve düzeltmeden sonra kayma oluyorsa, tedavi için kapalı düzeltme ve K-teli ile perkütan tespit gereklidir. Başparmak metakarp cisim kırığının tedavisindeki açık cerrahi düzeltme endikasyonları;

1. Kapalı düzeltmenin yapılamaması,

2. Çoklu metakarp veya el kırıkları,

3. Açık kırıklar,

4. Patolojik kırıklar,

5. Belirgin çok parçalı kırık olması,

6. Segmenter kemik kaybı varlığı olarak özetlenebilir.

Başparmak cisim kırıklarında tespit teknikleri açısından, diğer metakarp cisim kırıklarında bahsi geçen teknikler güvenle kullanılabilir. Eğer plak-vida tespiti kullanılıyorsa, kararlı tespit sağlanıp erken harekete başlamak ve immobilizasyon uygulamamakta yarar vardır.

\section{Başparmak kaidesi kırıkları, çıkıkları ve kırıklı- çıkıkları}

Başparmağın diğer dört parmağın karşısına gelmesini, kaba ve ince kavramanın amacına ulaşabilmesini sağlayan KMK (aslında trapeziometakarpal - TM) eklemin hareketli, kararlı ve ağrısız olarak kalmasını sağlamak, bu bölgede olan yaralanmaların tedavisinin temel hedefidir. Yaklaşımın felsefesi bu şekilde olunca, başparmağın kaidesini içeren eklem içi kırıklar, çıkıklar ve kırıklı-çıkıklar özel öneme sahiptir.

Rolando kırı̆̆ı, başparmak metakarp kaidesinin eklem-içi çok parçalı kırığıdır; "T" veya "Y" şeklinde olan tipleri ile karşımıza çıkar. Trapezyumda kırık olması nadirdir. ${ }^{[8]}$ Eklem yüzünün yeniden oluşturulması temel hedef olduğu için, büyük parçalı kırıklarda açık düzeltme ve plak-vida ile tespit tercih edilmelidir. Eklem yüzündeki dizilim kapalı düzeltme ile kısmen sağlanabiliyorsa, traksiyonda perkütan K-teli ile tespit kullanılabilir. Ancak, çok parçalı kırık varsa kullanılabilecek bir yöntem, kemik torbası prensibinden yararlanarak, traksiyonda konan eksternal fiksatörle eklem yüzünün restore edilmesidir. Tekniğe ilave olarak kemik greftlemesi de yapılabilir. ${ }^{[26]}$

Bennett kırığı olarak bilinen patoloji aslında başparmak kaidesinin kırıklı-subluksasyonunu tanımlar. Sadece kırık olarak ifade edilmesi, anatomik patolojiyi ifadede eksikliğe yol açmaktadır. Beak bağının (TM eklem kararlıı̆ı̆ına katkıda bulunan en önemli bağdır) yapıştığı kemiğin yerinde kalması, bu parçadan ayrılan metakarp kaidesinin dorsoradyal ve proksimale sublukse olması patolojiyi tam olarak ifade eder. ${ }^{[6,8]}$ Mediyaldeki küçük parça aslında yerinde kalmaktadır ve voler oblik bağ (Beak lig.) aracılığı ile ikinci parmakla ilişkisinin devam ettirir. Bununla beraber, kırık metakarpal cismi, abductor pollicis longus ve tenar intrensek kaslar ile proksimale ve laterale deplase olur. Bu tip kırıklı-çıkıklar kaymaya eğilimlidir ve kararlı değildir; bu yüzden daha agresif tedavi edilmelidir. Yetersiz yerleştirme ve yerine koyma, posttravmatik artrite ve sakatlığa neden olabilir. Bennett kırıklı-subluksasyonlarında, eğer eklemde basamaklaşma 2 mm'den fazla ise, kapalı düzeltme ve yerine koyma sonrası K-teli ile perkütan tespit yapılır. Kapalı redüksiyonda, longitudinal traksiyon, sublukse olan parçanın dorsalden volara doğru itilmesi ve başparmağa hafif pronasyon uygulamak gereklidir. Tespit için en az iki K-teli kullanılmalıdır; biri büyük parçayla volar-mediyaldeki küçük parçayı tespit ederken, diğer tel konsantrik olarak redükte edilen eklemi tespit eder (metakarptan trapezyuma). Başparmak dört hafta kadar alçı içinde tutulur ve dört hafta sonunda K-telleri ve alçı çıkarılır. Splint verilerek kontrollü harekete başlanır. Eğer işlem kapalı olarak başarılı olmuyorsa, açık yerine koyma ve yerleştirme sonrası vida veya K-telleri ile tespit uygulanır; gerekliyse kemik grefti uygulanmalıdır. ${ }^{[6,8,15]}$ Eklemin konsantrik olarak yerine konması ve eklem yüzünün restore edilmesi temel ve vazgeçilemez prensiplerdir. Lutz ve arkadaşları, Bennett kırıklı-sublusasyonunda açık redüksiyon ve içeriden tespitle, kapalı redüksiyon ve perkütan K-teli tespitini kıyaslamışlar ve ağrı, hareket genişliği, çimdikleme ve kavrama gücü açısından her iki teknik arasında bir fark tespit edememişlerdir (Seviye III kanıt). ${ }^{[27]}$

Başparmak kaidesinin kırık olmadan izole çıkığı oldukça nadirdir. Akut çıııklarda eklem yerine konabilse de, nihai durumu eklem yerine konduktan sonra elde edilen kararlılık belirleyecektir. TM eklemin kararlı olması kuvvetli kavrama ve erken osteoartritin gelişmesinin önlenmesi bakımından mutlak gereklidir. Eklem yerine konduktan sonra, Eaton-Littler tarafindan tanımlanan, flexor carpi radialis'in (FCR) bir kısmı kullanılarak 
yapılan bağ rekonstrüksiyonlarının sonucu yüz güldürücüdür. ${ }^{[6,8]}$

\section{Metakarpta segmenter kemik kaybı}

Metakarpta segmenter kemik kaybının olduğu açık kırıklarda tedavi zordur. Segmenter metakarp kemik kaybının olduğu yaralanmalara değişik derecelerde yumuşak doku kaybı eşlik eder. Metakarp uzunluğu, uygun yumuşak doku uzunluk gerilimi göz önünde tutularak devam ettirilmelidir. İki evreli tedavi yapılır; ilk evrede uygun bir eksternal fiksatörle, transvers K-telleri ile yanındaki metakarpa tespit ya da K-telini kanal içi bir boşluk doldurucu olacak şekilde yapılandırılarak metakarp uzunluğu sağlanır, bu seansta var olan yumuşak doku defekti giderilir. Ikinci evre, metakarpın kesin rekonstrüksiyonunu içerir. Kemik defekt, iliak kanattan alınan otojen kortikospongiyöz greftlerle köprülenir. Greft plak-vida, kanal içi tel veya K-telleri ile tespit edilebilir. ${ }^{[28,29]}$

\section{KOMPLIKASYONLAR}

Metakarp kırı̆ıını etkileyen deforme edici güçler, spiral veya oblik kırıktan sonra, parmakta kısalmaya neden olur. Parmaktaki kısalma ekstansör tendonları, fleksör tendonlar ve intrensek kaslardan daha fazla etkiler. Parmakta 2 mm'lik kısalma $7^{\circ}$ ekstansiyon yetersizliğine neden olur. Metakarpofalengeal eklemin $20^{\circ}$ hiperekstansiyon yaptığı düşünülürse, $6 \mathrm{~mm}$ 'den fazla kısalma kabul edilmez. ${ }^{[28]}$

Hem konservatif, hem de cerrahi tedavi sonrası komplikasyon gelişebilir. Kırı̆̆ın kapalı yöntemlerle tedavisi yanlış kaynama ve eklem sertliğine neden olabilir. Cerrahi tedavi, implantla ilişkili şikayetlere, tendon kopmalarına, yapışıklıklarına ve osteomiyelite neden olabilir.

\section{Yanlış kaynama}

Eklem içi veya eklem dışı olabilir. Eklem dışı yanlış kaynama açısal veya rotasyoneldir. Açısal yanlış kaynama ya sagittal ya da frontal plandadır; her ikisi de fonksiyonel ve kozmetik deformitelere neden olabilir. Genellikle, sagittal planda, apeksi dorsalde bir açılanma vardır. Koronal plandaki deformite daha az tolere edilir ve muayenede parmakta açılanmaya neden oluyorsa düzeltilmelidir.

Rotasyonel yanlış kaynamada deformite distaldedir ve etkilenmiş parmak yanındaki parmağın üzerine biner; genelde spiral veya oblik kırıklar sonrası oluşur. Rotasyonel deformite kabul edilemez. Beş derecelik malrotasyon $1,5 \mathrm{~cm}$ 'lik üst üste binmeye neden olabilir. ${ }^{[28]}$ Fonksiyonel düzeltme için düzeltici osteotomi planlanabilir.

\section{Enfeksiyon}

Açık kırıklarda enfeksiyon, cerrahi tedavi edilen kapalı kırıklardan daha sıktır. Enfeksiyon direkt olarak yaranın kontaminasyonu ve yumuşak doku örtümü ile ilişkilidir. Açık kırıklarda enfeksiyonu önlemek için yara debridmanı ve yıkanması önemlidir. Osteomiyelit ciddi bir komplikasyondur. Tanı, klinik, radyolojik inceleme ve pozitif kültür sonrası konur. Cerrahi dışı tedavinin değeri azdır. Kırık ve osteomiyelit durumunda iki evreli tedavi basamağı uygulanır. Illk olarak, varsa tüm implantlar çıkarılır, enfekte doku debride edilir, kanayan kemik doku çıkıncaya kadar kemik çıkarılır ve aynı seansta boşluk antibiyotikli kemik çimentosu ile doldurulur. İkinci evrede enfeksiyon kontrol altında alındıktan sonra kesin rekonstrüktif cerrahi yapılır. ${ }^{[29,30]}$

\section{Kaynamama}

Kaynamama nadir görülmektedir; genellikle, kemik kaybı, enfeksiyon ve yetersiz tespit sonrası oluşur. Kaynamama alanının rezeksiyonu, greftleme ve kararlı tespit ile tedavi edilir.

\section{Tendon yapışıklıkları}

Bu durum seyrektir; genellikle, tendon laserasyonları, ezilme tipi yaralanmaların eşlik ettiği durumlar veya geniş açılımla travmatik şekilde yapılan cerrahiden sonra görülür.

\section{Intrensek kas disfonksiyonu}

Genellikle, tanı konulamamış kompartman sendromu sonrası veya sinir hasarı sonrası oluşur. Tendon transferi gerekebilir.

Sonuç olarak metakarp kırıklarının tedavisinde başarıyı birçok etmen belirlemektedir. Konservatif tedavide açılanmanın ve kısalığın kabul edilebilir sınırlar içinde olması ve rotasyonel deformitenin olmaması esastır ve takipte bu parametrelerdeki değişiklikleri tespit edebilmek için yakın klinik izlem gereklidir. Tedavi sonrası eklem kontraktürlerini engellemek için uygun pozisyonda atelleme ve kontrollü erken harekete başlanması gereklidir. Cerrahi tedavide kırık geometrisine göre K-teli, vidalar ve plak-vidalar uygulanmaktadır. Mümkün olduğu kadar MF eklemi çaprazlayan K-tellerinden kaçınılması, oluşabilecek kontraktürlerin engellenmesi açısından önemlidir. Tedavide plak-vida kullanılacaksa, düşük profilli malzemeler ekstansör mekanizmayı rahatsız etmeyecek şekilde kullanılmalıdır ve kararlı tespit sağlanmış ise erken harekete başlanmalıdır. 


\section{KANITA DAYALI TIP AÇISINDAN METAKARP KIRIKLARI}

Metakarpal kırıklarında, eklem-içi kırıklar dışlandığında (eklem yüzeyi düzeltilmesi prensibinden dolayı cerrahi ve konservatif tedaviyi kıyaslayacak çalışma yapmak teknik ve etik olarak çok mümkün değil gibi gözükmektedir), ileriye dönük olarak konservatif tedaviyle cerrahi tedaviyi kıyaslayan çalışmalar literatürde mevcut değildir. ${ }^{[7]}$ Bu yüzden kanıtlarla ortaya konmuş "doğru" tedavi yönteminden bahsetmek çok mümkün değildir. Metakarp kırıklarının tedavisinde oluşan bilgi birikimi daha çok Seviye IV kanıt yayınlarına dayanmaktadır. ${ }^{[7]}$

Literatürde mevcut olan en iyi kanıtlara göre, bir metakarp kırı̆̆ının tedavisine, eğer redüksiyon iyi ise bir çeşit immobilizasyon uygulayarak konservatif olarak başlamalıdır (Seviye II, IV kanıt).[17,19] Kırık pozisyonunda olabilecek değişiklik açısından yakın takip edilmelidir. Eğer redüksiyon kararlı olarak kalmış ise, immobilizasyon iki hafta gibi erken olabilecek bir süreden sonra devam ettirilmeyebilir (Seviye II, IV kanıt). ${ }^{[7,17,19]}$

\section{KAYNAKLAR}

1. Henry MH. Fractures and dislocation of the hand. In: Bucholz RW, Heckman JD, Court-Brown C, editors. Rockwood and Green's Fractures in Adults. 6th ed. Philadelphia, Pa.: Lippincolt Williams \& Wilkins; 2005. p.771-855.

2. Ashkenaze DM, Ruby LK. Metacarpal fractures and dislocations. Orthop Clin North Am 1992;23(1):19-33.

3. Axelrod TS. Metacarpal fractures. In: Light TR, editor. Hand Surgery Update. 2nd ed. Rosemont, II: Am Soc Surg Hand; 1999. p.11-17.

4. Light TR, Bednar MS. Management of intra-articular fractures of the metacarpophalangeal joint. Hand Clin 1994;10(2):303-14.

5. Brewerton DA. A tangential radiographic projection for demostrating involvement of metacarpal heads in rheumatoid arthritis. Br J Radiol 1967;40(471):233-4.

6. Lehman $T$, Hildenbrand J, Rayan GM. Fractures and ligament injuries of the thumb and metacarpals. In: Trumble TE, editor. Principles of Hand Surgery and Therapy. 2nd ed. Philadelphia: Saunders/Elsevier; 2010. p.35-59.

7. Friedrich JB, Vedder NB. An evidence-based approach to metacarpal fractures. Plast Reconstr Surg 2010;126(6):22059. CrossRef

8. Baltera RM, Hasting $\mathrm{H}$, Sachar $\mathrm{K}$, Jitprapaikulsarn $\mathrm{S}$. Fractures and dislocations: Hand. In: Hammert WC, Boyer MI, Bozentka DJ, Calfee RP, editors. ASSH Manual of Hand Surgery. Philadelphia, PA: Lippincott Williams \& Wilkins; 2010. p.86-215.

9. Markewitz AD. Fractures and dislocations involving the metacarpal bone. In: Trumble TE, Budoff JE, Cornwall R, editors. Hand, elbow, and shoulder: core knowledge in orthopaedics. Philadelphia: Mosby-Elsevier; 2006. p.38-55.

10. Margles SW. Intra-articular fractures of the metacarpophalangeal and proximal interphalangeal joint. Hand Clin 1988;4(1):67-74.

11. Hastings $\mathrm{H}$ 2nd, Carroll $\mathrm{C}$ 4th. Treatment of closed articular fractures of the metacarpophalangeal and proximal interphalangeal joint. Hand Clin 1988;4(3):503-27.
12. Freeland $A E$. Hand fractures: repair, reconstruction and rehabilitation. Philadelphia: Churchill Livingstone; 2000.

13. Leung YL, Beredjiklian PK, Monaghan BA, Bozentka DJ. Radiographic assessment of small finger metacarpal neck fractures. J Hand Surg Am 2002;27(3):443-48.

14. Ali A, Hamman J, Mass DP. The biomechanical effect of angulated boxer's fractures. J Hand Surg Am 1999;24(4):835-44.

15. Stern PJ. Fractures of the metacarpals and phalanges. In: Green DP, Hotchkiss RN, Pederson WC, Wolfe SW, et al., editors. Green's operative hand surgery. Vol 1, 5th ed. Philadelphia: Elsevier; 2005. p.277-341.

16. Hofmeister EP, Kim J, Shin AY, Comparison of 2 methods of immobilization of fifth metacarpal neck fractures: prospective randomized study. J Hand Surg Am 2008;33(8):1362-8. CrossRef

17. Poolman RW, Gosling JC, Lee JB, Statius Muller M, Steller EP, Struijs PA. Conservative treatment for closed fifth (small finger) metacarpal neck fractures. Cochrane Database Syst Rev 2005;(3): CD 003210.

18. Seitz $W H$, Froimson A. Management of malunited fractures of metacarpal and phalangeal shafts. Hand Clin 1988;4(3):529-36.

19. Al-Qattan MM. Outcome of conservative management of spiral/long oblique fractures of the metacarpal shaft of the fingers using a palmar splint and immediate mobilisation of the fingers. J Hand Surg Eur Vol 2008;33(6):723-7. CrossRef

20. Kozin SH, Thoder JJ, Lieberman G. Operative treatment of metacarpal and phalangeal shaft fractures. J Am Acad Orthop Surg 2000;8(2):111-21.

21. Klein DM, Belsole RJ. Percutaneous treatment of carpal, metacarpal and phalangeal injuries. Clin Orthop Relat Res 2000;(375):116-25.

22. Liew $\mathrm{KH}$, Chan BK, Low CO. Metacarpal and proximal phalangeal fractures--fixation with multiple intramedullary Kirschner wires. Hand Surg 2000;5(2):125-30.

23. Cain JE Jr, Shepler TR, Wilson MR. Hamatometacarpal fracture-dislocation: classification and treatment. J Hand Surg Am 1997;12(5 Pt 1):762-7.

24. Yoshida R, Shah MA, Patterson RM, Buford WL Jr, Knighten $J$, Viegas SF. Anatomy and pathomechanics of ring and small finger carpometacarpal joint injuries. J Hand Surg Am 2003;28(6):1035-43.

25. Garcia-Elias M, Dobyns JH, Cooney WP 3rd, Linscheid RL. Traumatic axial dislocation of the carpus. J Hand Surg Am 1989;14(3):446-57.

26. Buchler U, McCollam SM, Oppikofer C. Comminuted fractures of the basilar joint of the thumb: combined treatment by external fixation, limited internal fixation, and bone grafting. J Hand Surg Am 1991;16(3):556-60.

27. Lutz $M$, Sailer R, Zimmermann R, Gabl M, Ulmer $H$, Pechlaner S. Closed reduction transarticular Kirschner wire fixation versus open reduction internal fixation in the treatment of Bennett's fracture dislocation. J Hand Surg Br 2003;28(2):142-7.

28. Balaram AK, Bednar MS. Complications after the fractures of metacarpal and phalanges. Hand Clin 2010;26(2):169-77. CrossRef

29. Freeland AE. External fixation for skeletal stabilization of severe open fractures of the hand. Clin Orthop Relat Res 1987;(214):93-100.

30. Diao E. Metacarpal fixation. Hand Clin 1997;13(4):557-71. 